\title{
Nail in the midbrain
}
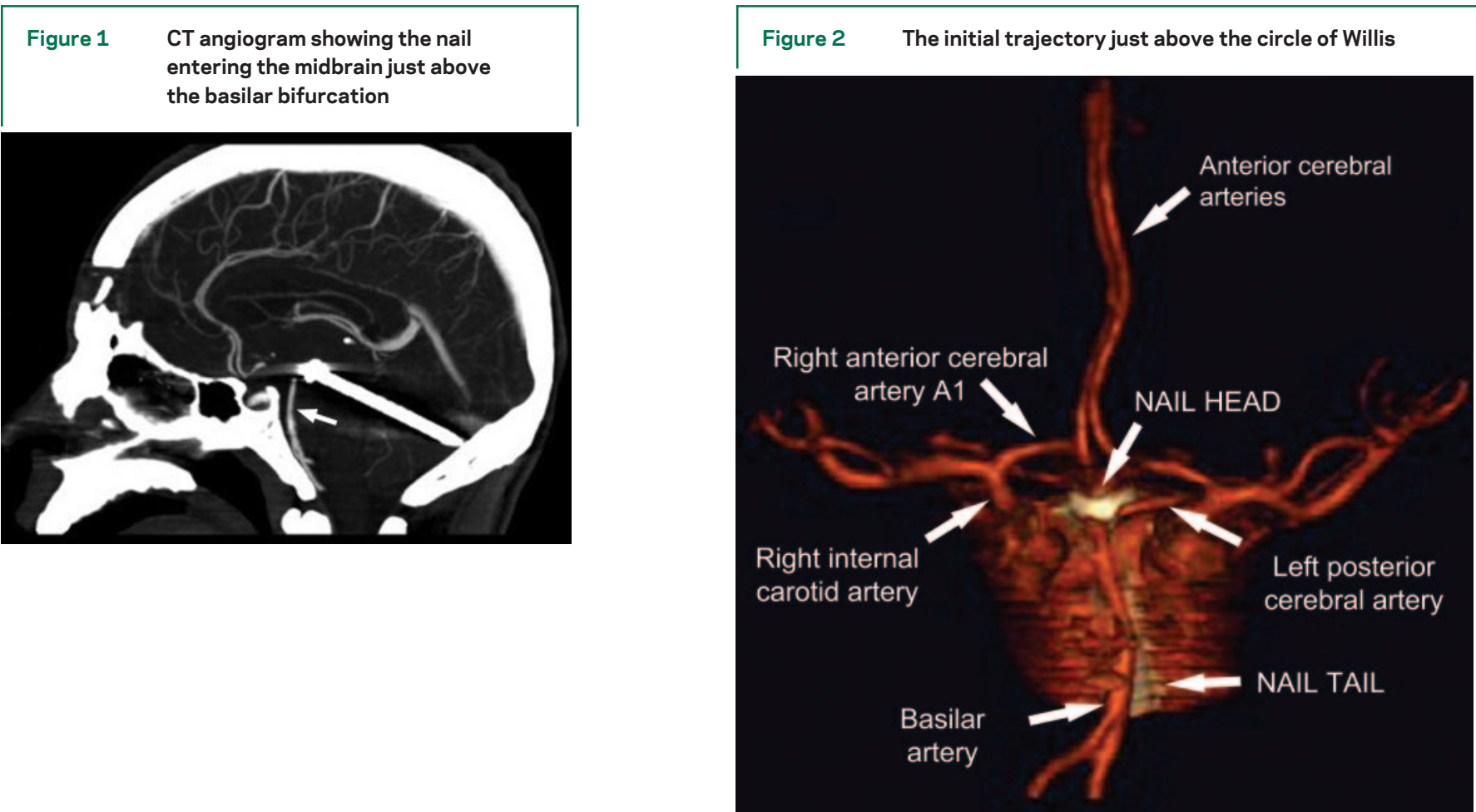

A 31-year-old man who had been shot with a nail gun was unresponsive at presentation, with unequal, nonreactive pupils. The frontal sinus and right frontal pole were debrided emergently. The $6.5-\mathrm{cm}$ nail was left in the midbrain and cerebellar vermis. He extubated himself on day 3, was verbally responsive, and was alert but confused. CT angiogram showed the nail entering the midbrain just above the basilar bifurcation (figure 1), with its initial trajectory just above the circle of Willis (figure 2). One month later, he exhibited slow mentation, dysarthria, and internuclear ophthalmoplegia, but was infection free, fully awake, alert, oriented, and ambulating with assistance.

Tamara Lazic, MD, * John Strugar, MD, * New Haven, CT

*Both authors contributed equally.

Disclosure: The authors report no disclosures.

Address correspondence and reprint requests to Dr. Tamara Lazic, Department of Internal Medicine, Yale University, New Haven, CT 06520; tamara.lazic@yale.edu 


\title{
Neurology
}

\author{
Nail in the midbrain \\ Tamara Lazic and John Strugar \\ Neurology 2009;72;1531 \\ DOI 10.1212/WNL.0b013e3181a2e91e
}

\section{This information is current as of April 27, 2009}

\section{Updated Information \& Services}

Subspecialty Collections

Permissions \& Licensing

\section{Reprints}

including high resolution figures, can be found at: http://n.neurology.org/content/72/17/1531.full

This article, along with others on similar topics, appears in the following collection(s):

All Clinical Neurology

http://n.neurology.org/cgi/collection/all_clinical_neurology All Imaging

http://n.neurology.org/cgi/collection/all_imaging

Information about reproducing this article in parts (figures,tables) or in its entirety can be found online at:

http://www.neurology.org/about/about_the_journal\#permissions

Information about ordering reprints can be found online:

http://n.neurology.org/subscribers/advertise

Neurology ${ }^{\circledR}$ is the official journal of the American Academy of Neurology. Published continuously since 1951, it is now a weekly with 48 issues per year. Copyright . All rights reserved. Print ISSN: 0028-3878. Online ISSN: 1526-632X.

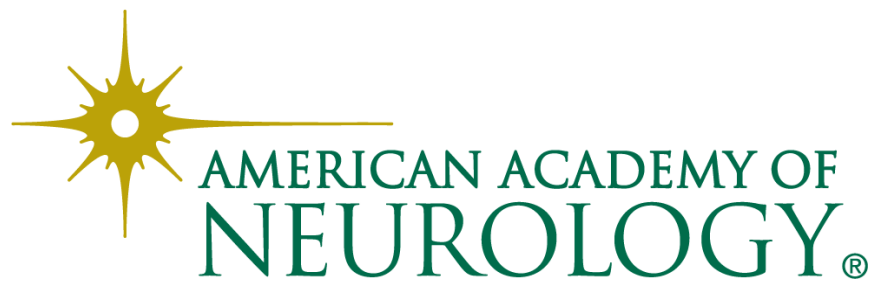

